\title{
Remote Sensing and GIS for Integrated Modeling and Analysis for Mapping of Groundwater Potential Zones in Sarada River Basin, Visakhapatnam, India
}

\author{
Nooka Ratnam Kinthada ${ }^{1, a}$ and Murali Krishna Gurram ${ }^{2, b^{*}}$ \\ ${ }^{1}$ Department of Geology, Adikavi Nannaya University, Raja Raja Narendra Nagar, \\ Rajamahendravaram - 533105, East Godavari (D.T.), Andhra Pradesh, India. \\ ${ }^{2}$ GIS Technology \& Applications Development, Xinthe Technologies Pvt. Ltd., $4^{\text {th }}$ Floor, SRK \\ Destiny, VIP Road, Visakhapatnam - 530003, Andhra Pradesh, India. \\ aratna_k12@yahoo.com, bmurali.krishna.gurram@gmail.com
}

\begin{abstract}
Keywords: Remote Sensing and GIS, Groundwater Potentiality, Integrated Modeling and Analysis, Sarada river basin in Visakhapatnam
\end{abstract}

\begin{abstract}
The study aimed at identifying and mapping groundwater potential zones in agricultural intensive Sarada river basin using Remote sensing and GIS technology. Zones of water potentiality were mapped integrating various information layers in GIS environment which eventually helped weighted modeling to arrive at the final outcome. Hydrogeomorphic units such as alluvial plains, valley fills, shallow weathered pediplains and deeply weathered pediplains were mapped. Eventually water potential zones in the basin were mapped and categorised them in to 'excellent', 'good', 'moderate' and 'poor'. The study highlighted the effective use of Remote sensing and GIS technology for integrated analysis, identification and mapping of the groundwater potential zones in the Sarada river basin.
\end{abstract}

\section{Introduction}

As the world population continues to grow with rapid pace it is increasingly becoming a burden on the natural and environmental resource like, land, water, forest, etc. which are very finite in nature. The human induced land utilization practices especially urbanization, industrialization, mining, grazing, deforestation, unscientific agricultural practices etc. are mostly unsustainable and further making the availability of these resources scarce. Among these resources potable water available in the form of groundwater is identified as crucial for the sustenance of any further development. While the existing groundwater resource continues to deplete, the efforts are always on for finding and exploring the new. The objective of groundwater exploration is to locate aquifers capable of yielding water of suitable quality in economic quantities for drinking, agricultural and industrial purposes.

Information pertaining to geology and field reconnaissance represents an important first step in any groundwater investigation. Traditionally groundwater identification studies are being carried out through geological and geophysical investigations by means of electrical conductivity, resistivity, drilling and other techniques. Similar studies on various river basins of India were attempted by researchers like Ravi Prakash and Mishra (1993), Mangrulkar et al. (1993). Since these methods are time consuming, tedious, labor and cost intensive, often the data collected through these methods are insufficient and the result often represent partial picture of the groundwater scenario and many a times prove unsuccessful. Application of Remote Sensing and GIS technology is highly effective for quickly ascertaining hydromorphological conditions and evaluating groundwater potential of a region. Remote sensing data has become increasingly valuable means for understanding geology and geomorphology and for effectively mapping subsurface water scenario.

Sarada river is one of the prime sources of water for Visakhapatnam district in the state of Andhra Pradesh. The region is predominantly agricultural and known for cultivating commercial crops like sugarcane and paddy which are high water dependent crops. There are some studies 
carried out on different aspects of the basin. Prudhvi Raju and Vaidyanadhan (1984) mapped the geomorphology of the basin using remote sensing techniques. Nooka Ratnam et al. (2014 \& 2013) studied land use/land cover, NDVI, geomorphometry for monitoring the health of micro-watersheds and hydrological scenario of the basin. The present study was carried out to ascertain the hydromorphological scenario to map the water potential zones in Sarada basin.

\section{Study Area}

The Sarada river basin is extended in an area of $2634.22 \mathrm{~km}^{2}$ (Fig. 1) located between $17^{0} 25^{\prime}$ to $18^{0} 16^{\prime} \mathrm{N}$ latitudes and $82^{0} 31^{\prime}$ to $83^{\circ} 07^{\prime} \mathrm{E}$ longitudes. The river originates at Ananthagiri hills with an altitude of 1500 mand flows $131.37 \mathrm{~km}$ south to join Bay of Bengal near Revuvatada and Bangarammapalem villages. The tributaries namely Isaka Gedda, Mala Gedda, Mamidivaka Gedda, Medra Gedda, Pedda Gedda and Vedurla Geddajoin the river on its right bank.

The major reservoirs built across the river are Raiwada near Devarapalli and Raiwada villages, Konam near Chidikada and Goppulapalem villages. The study area falls in the Survey of India (SoI) toposheets of 1:50,000 scale numbered, $65 \mathrm{~J} / 08,12,16,65 \mathrm{~N} / 04,65 \mathrm{~K} / 05-15$ and $65 \mathrm{O} / 01$ 03. Fig. 1 shows the study area subset of IRS-P6 Resourcesat image used as a source for base data.

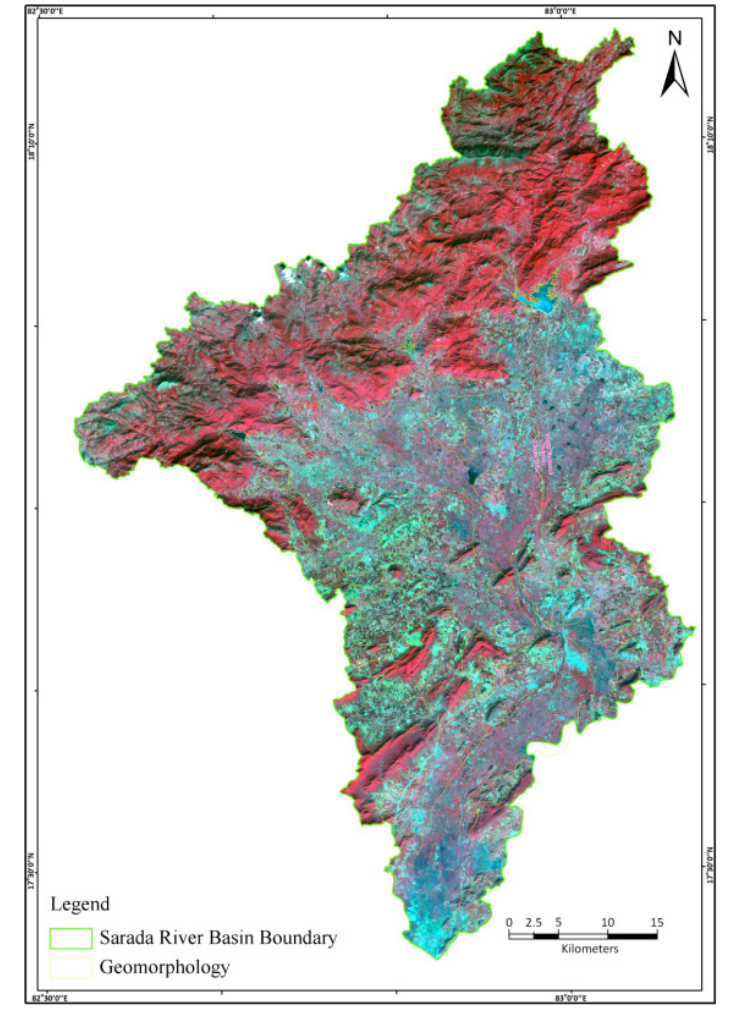

Figure 1: Resorcesat-1 image subset used as the data source for the study area.

\section{Methodology}

In order to identify, categorize and map the groundwater potential zones in the Sarada River Basin, a comprehensive analysis was done by taking various map composites for integration and evaluation based on weighted criteria. An integrated analysis was carried out using Remote sensing data and GIS technology. The study considers lithology, hydrogeomorphology, lineaments as principal parameters for delineating groundwater favorable zones. The methodology involves preparation of geomorphological map using IRS-P6 LISS-III satellite imagery. A geological map (structural and lithological) published by Survey of India (SOI)on 1:50,000 scale, ASTER (DEM) and field observations also taken as reference for the study. Detailed field checks have been carried out to confirm the observations. Information layers such as lithological structure, lineament density, drainage, land use have been generated for further investigation. Weights were assigned to each 
layer and corresponding units depending on their ability to withhold the groundwater. Groundwater potential zones are deduced and mapped by integrating the thematic information layers in the GIS environment.

\section{Hydrogeomorphology}

Ray and Raina (1973) described the significance of hydro, geomorphological and geological parameters for identifying groundwater prospective zones in the Kotipally catchment. Therefore, geomorphic units in the study area with respect to their water bearing nature are mapped and described in the sections below.

\section{Alluvial Plain}

A level or gently sloping tract or a slightly undulating land surface produced by the deposition of alluvium is called as alluvial plain. Alluvial plains are composed of various proportions of gravel, pebble, sand and silt. Near the Rambilli coast, the alluvial plain consists of sand, clay and silt. In the upper reaches of the river basin, the alluvial plain is confined to a narrow zone (about 2 $\mathrm{km}$ ) and becomes wider (about $10 \mathrm{~km}$ ) in the plains. The thickness of the alluvial deposits also increases in the downstream area with a thickness of 15 to $25 \mathrm{~m}$. The alluvial plains have a high infiltration rate and hence, a low runoff potential. They may be favorable for drawing groundwater through shallow and deep wells.

\section{Valley Fills}

In filled channel/valley fills occur in the lower part of the pediplain, along valley channelways, which have got silted up. This zone is expressed as the filled-up, darker toned, cultivated misfit channel-ways over hard rock terrain, with good moisture and recharge conditions. Apart from alluvial deposits along valley fills (upper horizons), this zone has a greater thickness (approximately $20+\mathrm{m}$ ) of the weathered zone (lower/deeper horizons) overlying bedrock. Hence, this zone may have very good groundwater prospects and is suitable, generally for dug-cum-bore-wells and shallow bore wells. In case the filled channel - ways show lineament/fracture control then they are considered even better for locating bore wells along fractures and their intersections.

\section{Denudational Hills}

Denudational processes are highly predominant in hilly areas. Hills with eroded surfaces are referred to as denudational hills and are further classified into high, moderately and less dissected zones. These hills with steeper slopes called Hummocky hills result in high runoff as water does not get time to infiltrate irrespective of lithology. Groundwater conditions in such areas are very poor to nil except for a few seasonal and perennial springs which may be fracture controlled. However, the valley flats within such hills could be prospects for local water supply.

\section{Pediment}

Pediment represents the rocky pavement (rock-cut surface) in upper part of the pediplain, immediately at the base of residual hills. Rocks are unweathered and jointed to partially weathered. They receive very limited recharge. Pediments generally express light photo tone, with scanty land cover, have overland and channel run-off with poor groundwater prospects.

\section{Shallow Weathered Pediplain}

The basin area is composed of a thick soil covered erosional surface developed over Granite Gneisses, Khondalites and Charnockites with low relief, gently sloping, very undulating terrain.

\section{Deeply Weathered Pediplain}

The basin area is composed of highly eroded granite gneisses, khondalites and charnockites with moderate relief and slopes. The surface is covered with a thin soil layer with varying degrees. 


\section{Palaeo Channels}

Plenty of palaeo channels are identified and mapped in Sarada basin, especially along the main river course at its lower reaches and at the areas where tributaries join in plains. It is noticed that most of these palaeo channels are confined to alluvial plains. These palaeo channels are significant in the area in terms of their high groundwater potentiality.

\section{Lineaments}

Lineaments play a significant role in groundwater exploration, particularly in hard rocks. Water well yields often show a positive correlation with linear features or with the intersection of two features (Gold, 1980 and Waters et al., 1990). Groundwater prospecting based on mapping of landforms and lineaments has become very common using remote sensing data (Sahai et al., 1983 and 1991; Srivastava and Bhattacharya, 2000). The lineaments can be utilized for rainwater harvesting for augmentation of the groundwater resources (Subba Rao, 2000).

Lineaments in the area are mapped from remotely sensed imagery (IRS-P6 LISS-III) which provides important information on sub-surface fractures that may control the movement and storage of groundwater. A total of 96 lineaments were mapped and was used to generate lineament density map (Fig. 2) based on the presence of lineaments per $\mathrm{km}^{2}$ area. The map shows predominant sets of lineaments present on the Charnockites, Granite Gneisses and Khondalites mostly in the direction of NE-SW following the general trend of the Eastern Ghats. These areas are divided into three zones such as, area without lineaments, areas with lineament density 0.198 to $0.563 \mathrm{~km} / \mathrm{km}^{2}$ and lineament density of $>0.563 \mathrm{~km} / \mathrm{km}^{2}$. Areas with lineament density 0.198 and 1.578 per $\mathrm{km}^{2}$ may meaningfully be taken as boundary values. Drawing the lineament density isopleths divides the basin into three density zones and implicitly into three zones of groundwater prospects. These lineament density zones are classified as poor, good and excellent in terms of occurrence of the groundwater. These are especially seen in the middle parts of the basin and also in some of the parts of southeast and southern parts in the study area.

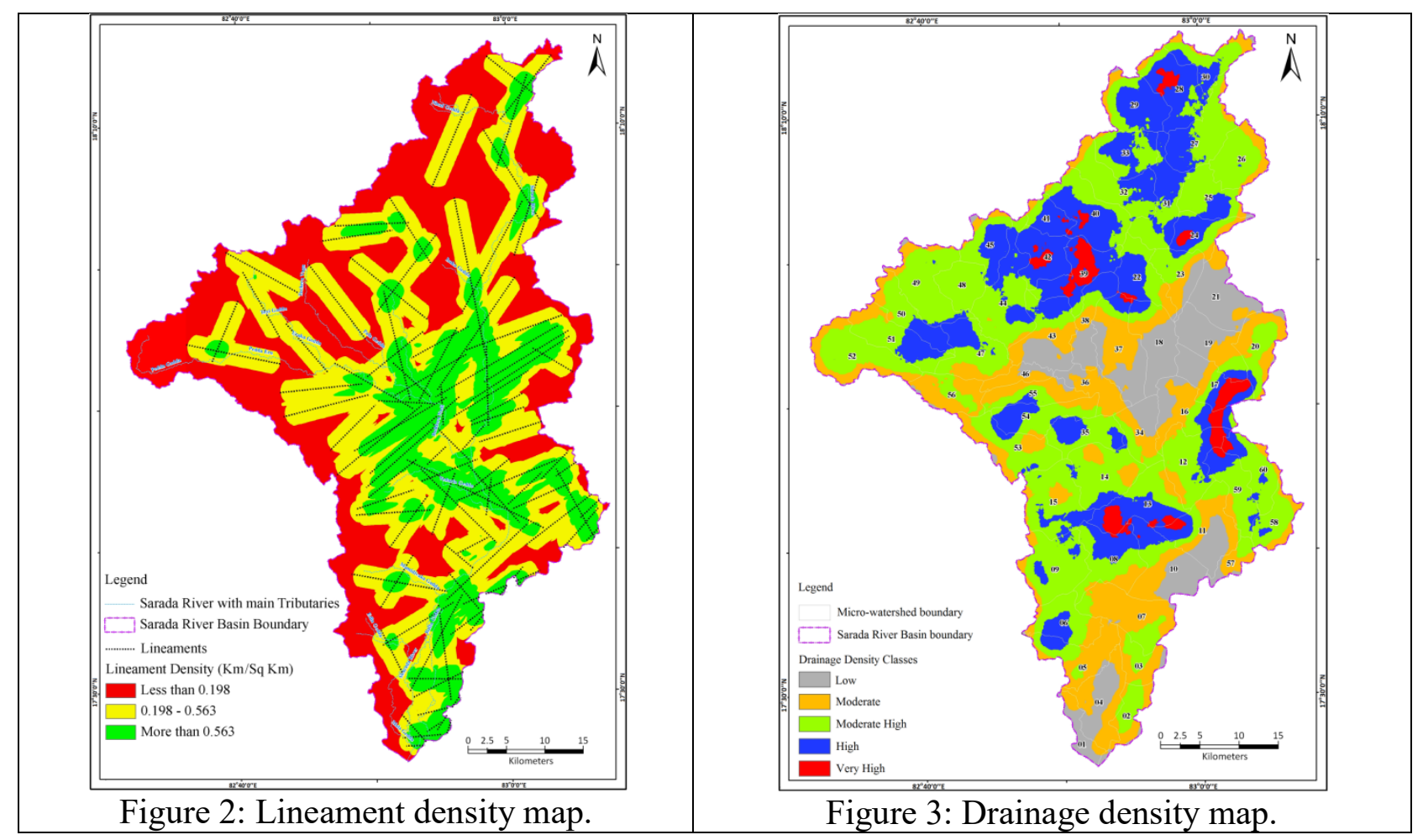

Drainage Density was calculated according to the expression $\mathrm{D}_{\mathrm{d}}=\sum \mathrm{Lu} / \mathrm{A}$

Where ' $D_{d}$ ' is the drainage density, ' $\sum \mathrm{Lu}$ ' is the total stream length and ' $A$ ' is the basin area. 
The ' $\mathrm{D}_{\mathrm{d}}$ ' value is calculated as $2.45 \mathrm{~km} / \mathrm{km}^{2}$, indicating 'moderate' to 'high' density. The 'moderate' drainage density value suggests that the Sarada River Basin has a moderate permeable sub-soil and a thick vegetative cover (Nag 1998).

\section{Geology and Soil}

The principal rock formations recorded and mapped in the study area are Charnockites, Granite Gneisses, Khondalites and Alluvium (Fig. 4). The accuracy of the mapping units was confirmed through subsequent field checks.

Most of the basin area is covered by soil categories such as, fine mixed, typic ustropepts (923.62 $\mathrm{km}^{2}$ with $35.06 \%$ cover) formed due to rock erosion. Clayey-skeletal, mixed, (paralithic), haplustalfs are the next major soil category covering an area of $333.03 \mathrm{~km}^{2}$ with $12.64 \%$ area. Fine mixed, typic rhodustalfs is the third largest soil class covering the basin with an area of $321.64 \mathrm{~km}^{2}$ with $12.21 \%$. The fourth largest soil category is fine, mixed, typic haplustalfs and fine, mixed, typic paleustalfs with an area of $244.66 \mathrm{~km}^{2}$ with $9.29 \%$ coverage. Fine, mixed, typic ustropepts clayeyskeletal, mixed, typic ustropepts are the fifth largest soil category covers $241.14 \mathrm{~km}^{2}$ with $9.15 \%$ area. The remaining categories cover a very small extent of the basin.

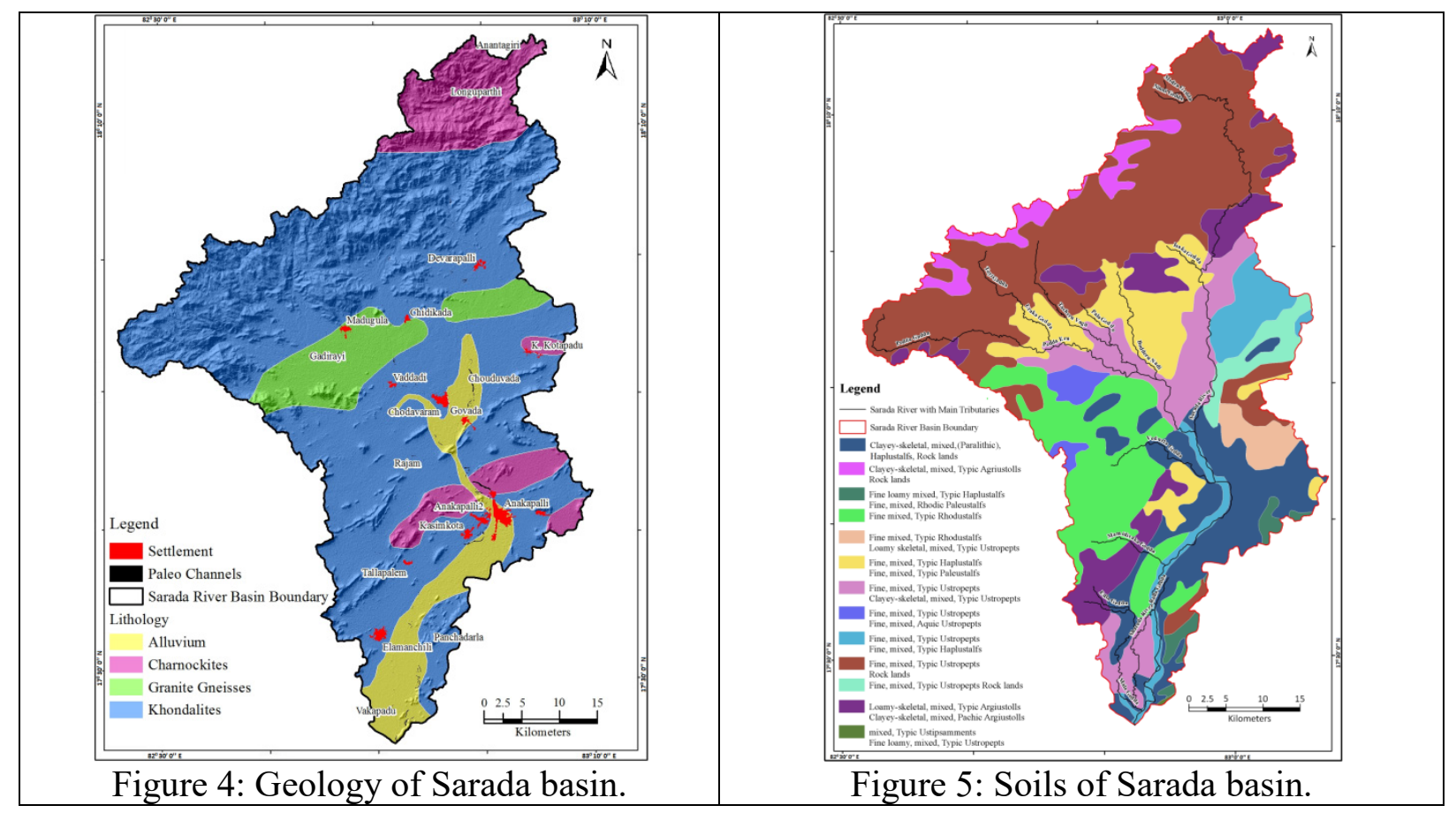

\section{Slope and Rainfall}

Slope map (Fig.6) was generated and mean slope for the basin computed as $2^{0} 1^{\prime}$ to $7^{0} 2^{\prime}$. The slope-range has been grouped into (six) classes extending from less than 20 to above 400 . The classes portray $41.28 \%$ of total area under 'gentle slope' where agriculture is predominant. About $5.84 \%$ of the area comes under very steep hills with forest cover. 


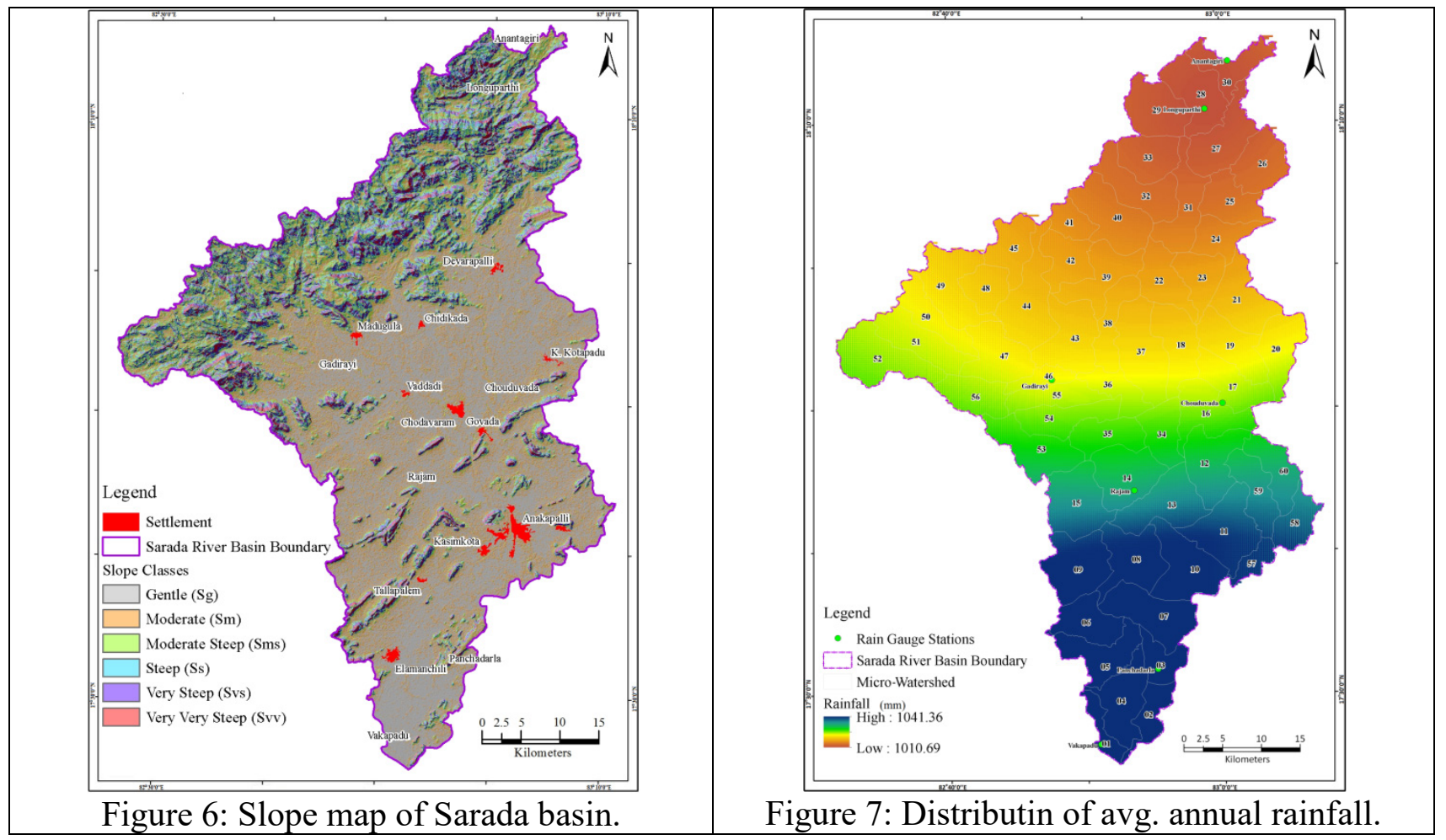

The basin experiences rainfall during June to September. The average annual rainfall is between 75 and $150 \mathrm{~cm}$. The rainfall is calculated in the range of 1010.69 to $1041.36 \mathrm{~mm}$ and mapped accordingly. Fig. 7 shows northern hilly region characterized by high elevation, dense vegetation and low population experiences high rainfall. The rainfall decreases gradually towards the coastal plains in the south where agriculture is predominant with high density of population.

\section{Land Use/Land Cover}

The land use/land cover phenomena (Fig. 8) mostly comprise agricultural land (53.39\%) with $1406.36 \mathrm{~km}^{2}$ area which includes both crop land $\left(619.9 \mathrm{~km}^{2}\right)$ and agricultural fallow $\left(786.46 \mathrm{~km}^{2}\right)$. Forest occupies $992.87 \mathrm{~km}^{2}(37.69 \%)$, while the built-up category accounts for $51.12 \mathrm{~km}^{2}$ which is $1.94 \%$ of the total area. Water bodies account for $0.85 \%$. Other land use/land cover categories include industries cover $0.34 \%$, rocky/barren land is $5.46 \%$, and aquaculture is $0.34 \%$. 


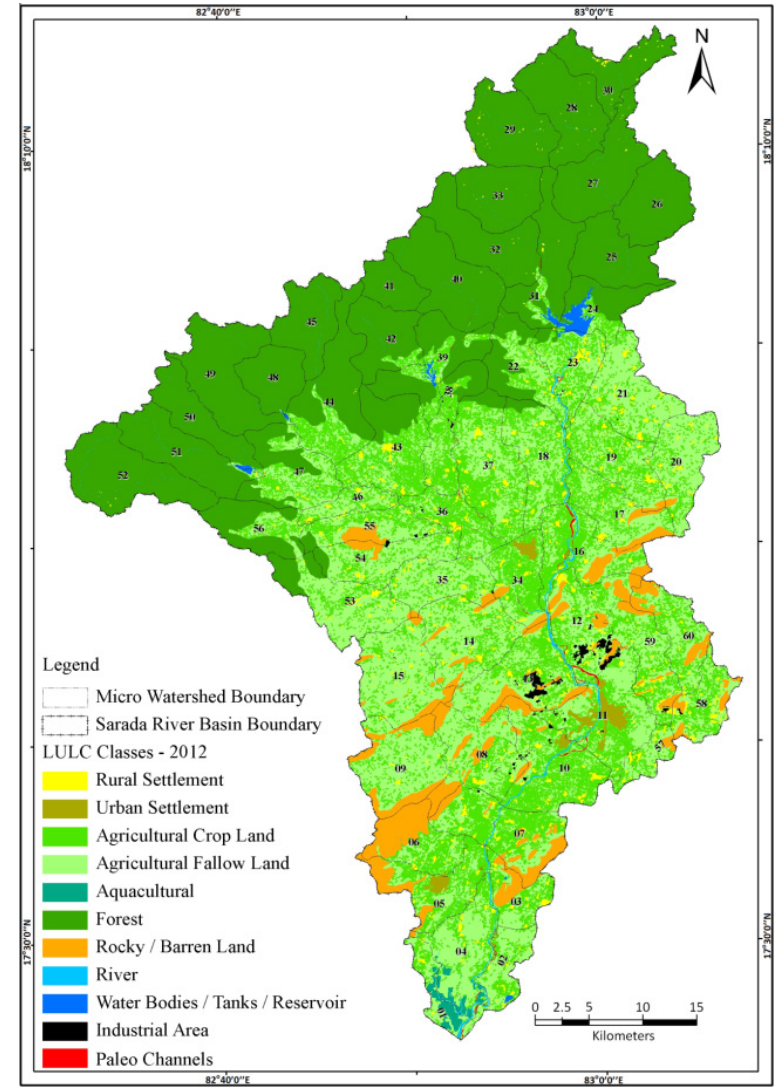

Figure 8: Land Use/Land Cover of Sarada basin.

\subsection{Integrated Analysis of Hydrogeomorphological Scenario}

Integrated analysis of landforms (geomorphology), rock structure (geology) such as, faults, folds, and fractures supported with ground truth information is essential for finding groundwater zones. Hydrogeomorphological units delineated in the basin with their groundwater prospect and their characteristics are summarized in Table 1.

Table 1: Hydrogeomorphological units of the Sarada River Basin.

\begin{tabular}{|l|l|l|l|l|}
\hline $\begin{array}{l}\text { Geomorphic } \\
\text { Units }\end{array}$ & \multicolumn{1}{|c|}{ Lithology } & \multicolumn{1}{|c|}{ Structure } & \multicolumn{1}{c|}{$\begin{array}{l}\text { Description or } \\
\text { Characteristics }\end{array}$} & \multicolumn{1}{c|}{$\begin{array}{l}\text { Groundwater } \\
\text { Occurrence }\end{array}$} \\
\hline $\begin{array}{l}\text { Alluvial } \\
\text { Plain (AP) }\end{array}$ & $\begin{array}{l}\text { Constitutes gravel, } \\
\text { sand, silt or clay } \\
\text { sized } \\
\text { unconsolidated } \\
\text { material }\end{array}$ & $\begin{array}{l}\text { Flat } \\
\text { adjacent to } \\
\text { river/stream and } \\
\text { fracture } \\
\text { controlled zones }\end{array}$ & $\begin{array}{l}\text { A level or gently sloping } \\
\text { tract or a slightly undulating } \\
\text { land surface produced by } \\
\text { deposition of alluvium. }\end{array}$ & $\begin{array}{l}\text { Good } \\
\text { to excellent } \\
\text { depending upon } \\
\text { alluvium } \\
\text { thickness }\end{array}$ \\
\hline $\begin{array}{l}\text { Valley Fills } \\
\text { (VF) }\end{array}$ & $\begin{array}{l}\text { Constitutes } \\
\text { boulders, cobbles, } \\
\text { pebbles, gravels, } \\
\text { sand, silt, and clay } \\
\text { sized grains of } \\
\text { varying lithology }\end{array}$ & $\begin{array}{l}\text { The Valleys } \\
\text { sometimes } \\
\text { fracture } \\
\text { controlled }\end{array}$ & $\begin{array}{l}\text { The unconsolidated } \\
\text { sediment deposited so as to } \\
\text { fill a valley. Sometime } \\
\text { controlled by fracture } \\
\text { forming a linear depression. }\end{array}$ & $\begin{array}{l}\text { Good to excellent } \\
\text { depending upon } \\
\text { the type of } \\
\text { lithology and } \\
\text { thickness of the } \\
\text { material deposited }\end{array}$ \\
\hline $\begin{array}{l}\text { Denudational } \\
\text { Hills (DNH) }\end{array}$ & $\begin{array}{l}\text { Khondalites and } \\
\text { Charnockites }\end{array}$ & $\begin{array}{l}\text { Jointed and } \\
\text { fractured }\end{array}$ & $\begin{array}{l}\text { High relief, steep sided } \\
\text { hills, Khondalites and } \\
\text { Charnockites }\end{array}$ & $\begin{array}{l}\text { Poor, except } \\
\text { along lineament } \\
\text { and depressions }\end{array}$ \\
\hline $\begin{array}{l}\text { Pediment } \\
\text { (BP) }\end{array}$ & $\begin{array}{l}\text { Khondalites } \\
\text { dominating the } \\
\text { underlying } \\
\text { lithology, and } \\
\text { Granite Gneisses }\end{array}$ & $\begin{array}{l}\text { Nearly flat to } \\
\text { gently sloping } \\
\text { topography. }\end{array}$ & $\begin{array}{l}\text { Broad, gently sloping, } \\
\text { erosional surface covered } \\
\text { with detritus of Khondalites } \\
\text { and the thin veneer of soil. }\end{array}$ & Moderate \\
\hline
\end{tabular}




\begin{tabular}{|l|l|l|l|l|}
\hline $\begin{array}{l}\text { Shallow } \\
\text { Weathered } \\
\text { Pediplain }\{\mathrm{SW}\})\end{array}$ & $\begin{array}{l}\text { Khondalites, } \\
\text { Granite Gneisses, } \\
\text { and Charnockites } \\
\text { dominates as the } \\
\text { underlying rock } \\
\text { unit }\end{array}$ & $\begin{array}{l}\text { Crises - crossed } \\
\text { by fractures and } \\
\text { joints etc. }\end{array}$ & $\begin{array}{l}\text { Thick soil covered erosional } \\
\text { surface developed over } \\
\text { Granite Gneisses, } \\
\text { Khondalites and } \\
\text { Charnockites. Low relief, } \\
\text { gently sloping, very } \\
\text { undulating terrain. }\end{array}$ & $\begin{array}{l}\text { Moderate, good } \\
\text { along lineaments } \\
\text { weathered zones, } \\
\text { and depressions }\end{array}$ \\
\hline $\begin{array}{l}\text { Deeply } \\
\text { Peathered } \\
(\mathrm{PP}\{\mathrm{DW}\})\end{array}$ & $\begin{array}{l}\text { Khondalites, } \\
\text { Granite Gneisses, } \\
\text { and Charnockites } \\
\text { dominates as the } \\
\text { underlying rock } \\
\text { unit }\end{array}$ & $\begin{array}{l}\text { Crises - crossed } \\
\text { by fractures and } \\
\text { joints etc. }\end{array}$ & $\begin{array}{l}\text { Thin soil covered erosional } \\
\text { surface developed over } \\
\text { Granite Gneisses, } \\
\text { Khondalites and } \\
\text { Charnockites. Moderate } \\
\text { relief, moderately sloping, } \\
\text { undulating terrain. }\end{array}$ & $\begin{array}{l}\text { Moderate, good } \\
\text { along lineaments } \\
\text { weathered zones }\end{array}$ \\
\hline Lineaments & $\begin{array}{l}\text { Cut across various } \\
\text { lithology }\end{array}$ & $\begin{array}{l}\text { Fault, fractures } \\
\text { etc. }\end{array}$ & $\begin{array}{l}\text { Fault line, fractures, joints, } \\
\text { shear zone, contact zones, } \\
\text { other linear features and } \\
\text { straight stream courses }\end{array}$ & $\begin{array}{l}\text { Good, excellent at } \\
\text { intersection of } \\
\text { lineament }\end{array}$ \\
\hline
\end{tabular}

Percent distribution of various hydrogeomorphic units have been calculated and tabulated in Table 2. Denudational hills are the prominent geomorphic units which cover majority of the basin area occupying $1,143.61 \mathrm{~km}^{2}$ with $43.41 \%$. The next major geomorphic unit is deeply weathered pediplain formed due to weathering occupies an area of $790.58 \mathrm{~km}^{2}$ and accounts for $30 \%$. Other important geomorphic units in the area are shallow weathered pediplain $\left(404.79 \mathrm{~km}^{2}\right.$ area with $15.37 \%)$, alluvial plain formed due to river action $\left(264.16 \mathrm{~km}^{2}\right.$ of area with $\left.10 \%\right)$, pediment $(21.98$ $\mathrm{km}^{2}$ of area with $\left.0.83 \%\right)$ and valley fills $\left(9.10 \mathrm{~km}^{2}\right.$ of area with $\left.0.35 \%\right)$.

Table 2: Areal extent of hydrogeomorphological units in the Sarada River Basin.

\begin{tabular}{|r|l|r|r|}
\hline \multirow{2}{*}{ S. No. } & \multicolumn{2}{|c|}{ Geomorphic Units } & \multicolumn{2}{c|}{ Area } \\
\cline { 3 - 4 } & & 264.16 & 10.03 \\
\hline 1 & Alluvial Plain (AP) & 9.10 & 0.35 \\
\hline 2 & Valley Fills (VF) & $1,143.61$ & 43.41 \\
\hline 3 & Denudational Hills (DNH) & 21.98 & 0.83 \\
\hline 4 & Pediment (BP) & 404.79 & 15.37 \\
\hline 5 & Shallow Weathered Pediplain $(\mathrm{PP}\{\mathrm{SW}\})$ & 790.58 & 30.01 \\
\hline 6 & Deeply Weathered Pediplain $(\mathrm{PP}\{\mathrm{DW}\})$ & $\mathbf{2 , 6 3 4 . 2 2}$ & $\mathbf{1 0 0 . 0 0}$ \\
\hline
\end{tabular}

Fracture density was mapped by overlaying the lineaments over hydrogeomorphic units (Fig. 9). 


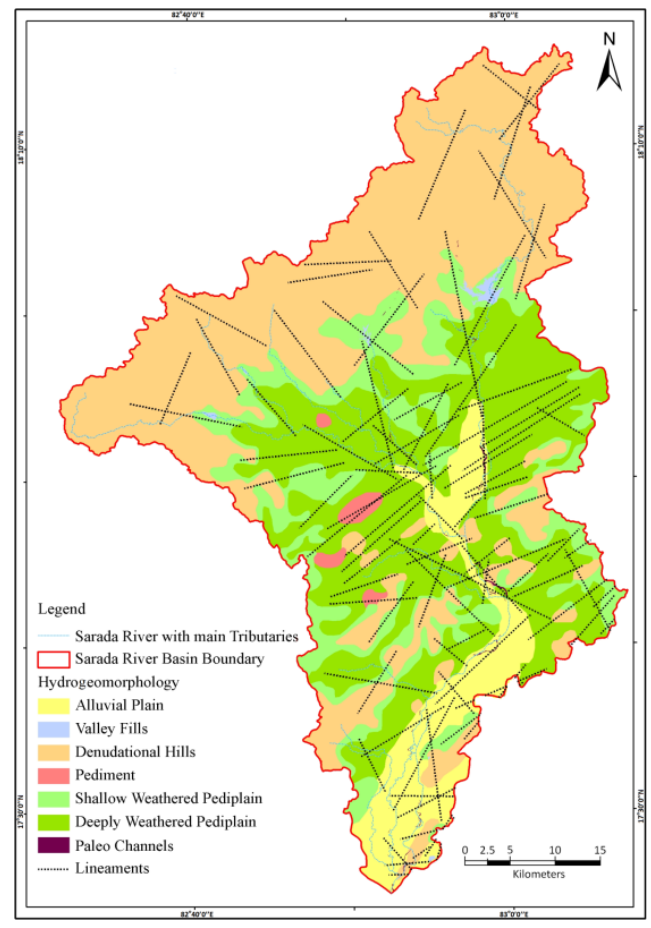

Figure 9: Map showing lineaments over different Hydrogeomorphological units.

In terms of groundwater occurrence, alluvial plains, valley fills and lineaments are considered 'excellent'. Shallow weathered pediplain and deeply weathered pediplain are considered 'good' and pediment as 'moderate'. On the other hand, denudational hills are considered poor for exploitation of the groundwater. These hydrogeomorphological units were classified into five categories from 'very good' to 'very poor'. It is noticed that areas where geomorphological units having occurrence of lineaments are found favorable for augmenting groundwater resource.

Analysis of the distribution of lineament density has shown that the lineament density values of 0.198 and 1.578 per $\mathrm{km}^{2}$ may meaningfully be taken as boundary values. Drawing the lineament density isopleths of these values divides the basin implicitly into three lineament density zones of high to low groundwater potential correspond to specific geomorphic units.

\subsection{Groundwater Favorable Zones}

Groundwater favorable zones indicate the degree of likeliness of its potentiality and considered as a base. Hydrogeomorphology units are considered as simple and direct indicators for demarcating groundwater favorable zones. These units interpreted from satellite image formed the basis for demarcating the groundwater favorable zones in the basin. The groundwater favorable zonation is done on a 1:50,000 scale by taking the SoI topographical maps as a background for mapping. The hydrogeomorphological units such as alluvial plain, valley fills, shallow weathered pediplain and deeply weathered pediplain are found to be the most favorable zones for groundwater exploration and development in the study area. Hence, these areas are marked as good to excellent favorable zones. These particular zones are mostly seen in the northern and middle portions of the Sarada River Basin and also in some parts in the southern portion of the basin. The groundwater favorable zones are mapped and shown in Fig. 10. 


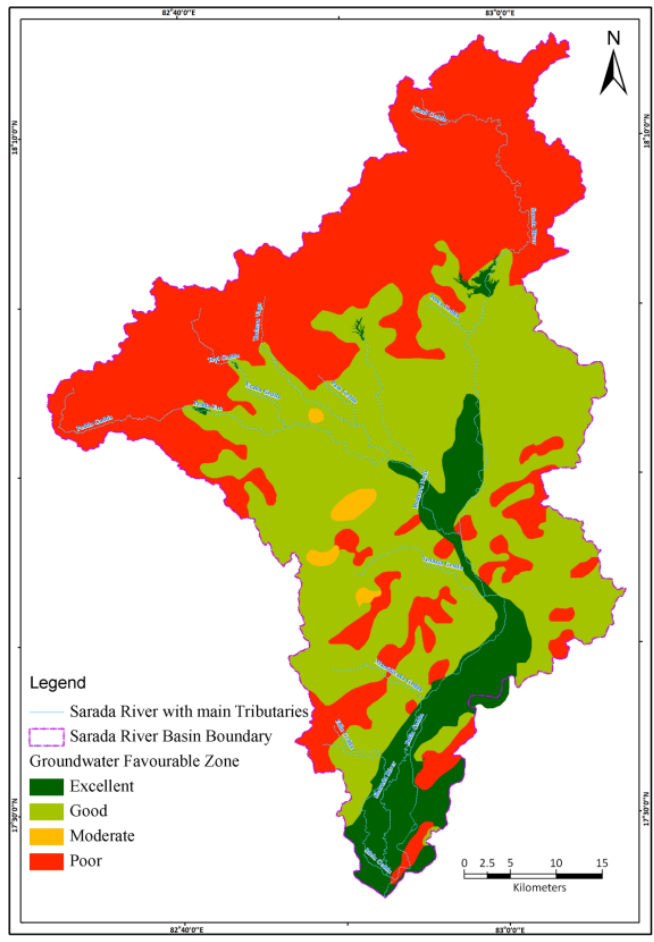

Figure 10: Map showing groundwater favorable zones in the Sarada River Basin.

\subsection{Groundwater Potentiality Mapping}

Various thematic data layers were integrated by employing weighted criteria subjectively for the identification of groundwater favorable zones in the study area, as seen in Table 3.

Table 3: Weighted criteria for mapping groundwater potential zones.

\begin{tabular}{|l|l|c|}
\hline Layer Name & Categories & Weightage Criteria \\
\hline \multirow{4}{*}{ Drainage Density } & Low & 2 \\
\cline { 2 - 3 } & Moderate & 4 \\
\cline { 2 - 3 } & Moderately high & 6 \\
\cline { 2 - 3 } & High & 8 \\
\cline { 2 - 3 } & Very high & 10 \\
\hline \multirow{5}{*}{ Hydrogeomorphological Units } & 1 \\
\hline & Low & 5 \\
\cline { 2 - 3 } & Moderate & 10 \\
\cline { 2 - 3 } & High & 1 \\
\cline { 2 - 3 } & Denudational Hills & 2 \\
\cline { 2 - 3 } & Pediment & 5 \\
\cline { 2 - 3 } & Deeply Weathered Pediplain & 6 \\
\cline { 2 - 3 } & Shallow Weathered Pediplain & 10 \\
\cline { 2 - 3 } & Alluvial Plain & 10 \\
\cline { 2 - 3 } & Valley Fills & 1 \\
\hline \multirow{5}{*}{ Land use/Land cover } & Forest & 2 \\
\cline { 2 - 3 } & Rocky/Barren Land & 4 \\
\cline { 2 - 3 } & Urban Settlement & 4 \\
\cline { 2 - 3 } & Rural Settlement & 6 \\
\cline { 2 - 3 } & Agricultural Fallow Land & 7 \\
\cline { 2 - 3 } & Agricultural Crop Land & 10 \\
\cline { 2 - 3 } & River & 10 \\
\cline { 2 - 3 } & Water Bodies / Reservoir & 10 \\
\cline { 2 - 3 } & Aquaculture & 2 \\
\hline
\end{tabular}


The weights are assigned to different mapping units of a thematic layer on a scale of 1 to 10 , subjectively, where value ' 1 ' indicates least significance while value ' 10 ' indicates the highest significance of the mapping unit. The integrated analysis results of composite units of different weights help computing the final score for each common area. Further categorization of final scores will result in the demarcation of groundwater potentiality zones of different categories. Based on these considerations various hydrogeomorphic units were classified into four categories of groundwater potential zones namely, excellent, good, moderate and poor.

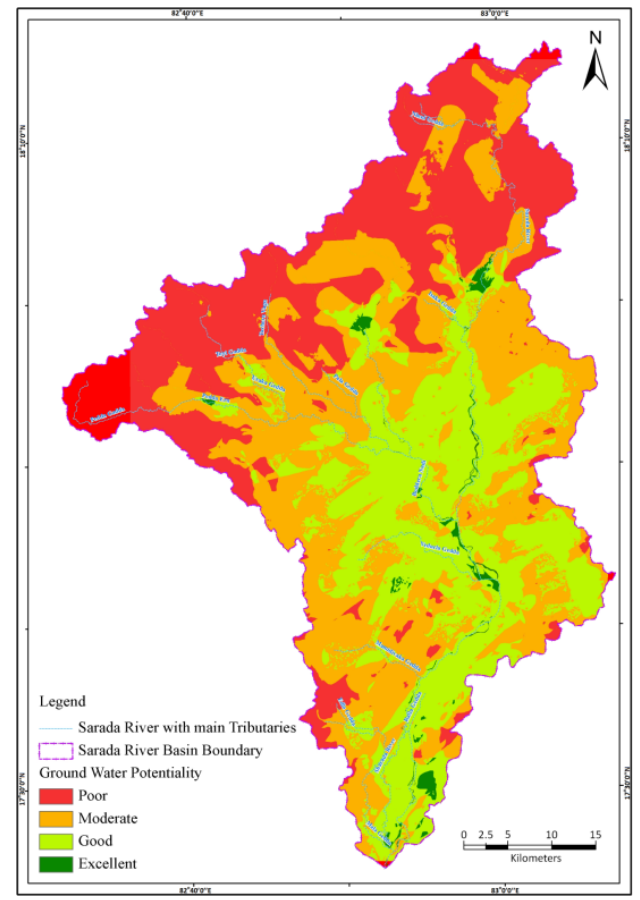

Figure 11: Groundwater potentiality map.

\section{Discussion}

Various hydrogeomorphic units are classified based on their potentiality and categorized as 'excellent', 'good', 'moderate' and 'poor'. These units namely alluvial plain, valley fills, shallow weathered pediplain and deeply weathered pediplain are most favorable zones for groundwater exploration and development, hence marked as 'good' and 'excellent'. Presence of more lineaments in the basin signifies excellent potential zones for groundwater development. Fig. 11 shows excellent groundwater potential zones in some northern and southern parts of the study area as compared to upper middle and east-southeastern part of the basin. The groundwater potential map clearly indicates alluvial plains adjacent to river/streams composed of sand, silt and clay with very low drainage density show very good potentiality. Valley fills associated with lineaments are found highly promising. On the other hand, zones with geological structures like, structural hills, denudation hills and residual hills are found with poor to very poor groundwater potential. These results are corroborated with observations from field checks in the basin. Photograph (Plate 1) shows an open well in the agricultural farm near Venkanna Palem and Murdhurty villages in the alluvial plains confirm abundance of groundwater. The information is very useful for further groundwater development in the study area. 


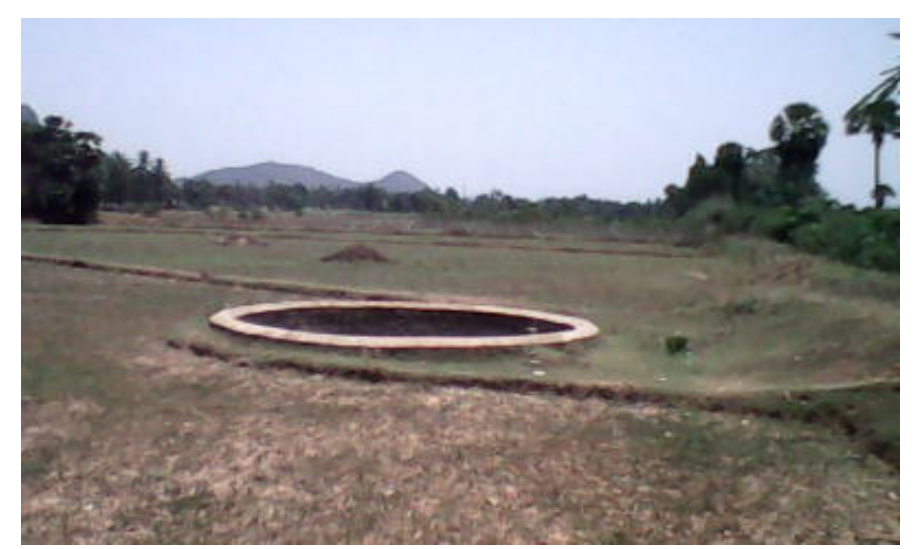

Plate 1: Open well of $6 \mathrm{~m}$ diameter with $5.2 \mathrm{~m}(\mathrm{bgl})$ water level used for agriculture along the road connecting Venkanna Palem and Murdhurty in the study area.

\section{Conclusions}

The study endeavored to characterize the geomorphological and hydromorphological arrangement in the basin, which is taken as the basis to identify and map water potentiality. A hydromorphological scenario deduced using IRS-P6 LISS-III data, delineating prominent units such as alluvial plain (AP), valley fills (VF), denudational hills (DNH), pediment (BP), shallow weathered pediplain ( $\mathrm{PP}\{\mathrm{SQ}\}$ ), and deeply weathered pediplain (PP $\{\mathrm{DW}\})$. Based on the considerations deduced from the integrated analysis using GIS, various hydrogeomorphic units have been mapped in the basin area andclassified them into four categories of groundwater potential namely, 'excellent', 'good', 'moderate' and 'poor'. Areas marked as 'good' and 'excellent' are found distributed mostly in the valley areas in north, middle and in some ofthe southern areas as compared to upper middle and east-southeastern parts of the basin. This study helps further development of groundwater resource to cater the drinking and irrigation water demands in the Sarada basin.

\section{References}

[1] Gold, D.P. (1980). Structural Geology, Chapter 14 in Remote Sensing in Geology, edit by Siegal, B. S. and Gillespie, A. R. John Wiley, New York. pp. 410-483.

[2] Nooka Ratnam K., Murali Krishna G., Amminedu E. and Venkateswara Rao V. (2013). Remote Sensing and GIS in the Geomorphometric Analysis of Micro-Watersheds for Hydrological Scenario Assessment and Characterisation - A Study on Sarada River Basin, Visakhapatnam District, India, International Journal of Geomatics and Geosciences, Vol. 4, No. 1, pp. 195-212.

[3] Nooka Ratnam K., Murali Krishna G., Amminedu E. and Venkateswara Rao V. (2014). Land Use/Land Cover and NDVI Analysis for Monitoring the Health of Micro-watersheds of Sarada River Basin, Visakhapatnam District, India, Journal of Geology \& Geosciences, Vol. 3, issue 2, pp. 146-153.

[4] Mangrulkar, A.D., Kondawar, V.K. and Krishnamurty, Y.V.N. (1993). Geo-environmental Characteristics and Identification of Hydro-potential Zones in Tansa and Bhatsi Reservoir Catchments, pp. 23-33.

[5] Prudhvi Raju, K.N. and Vaidyanathan, R. (1984). Photohydrogeomorphology of the Sarada River Basin in Visakhapatnam District, A.P. J. Assoc. Expl. Geophysicists, Vol.4(3),pp.31-39.

[6] Ravi Prakash, S. and Mishra, D. (1993). Identification of groundwater Prospective Zones by Using Remote Sensing and Geoelectrical Methods in and around Saidnagar Area, Dakor Block, Jalaun District, Uttar Pradesh, Photonirvachak, Journal of the Indian Society of Remote Sensing, Vol. 21, No.4. 
[7] Ray and Raina (1973). Hydro-Geomorphological Units coupled with Geological Parameters in Kotipally Catchment Area of Hyderabad. Indian Journal of Remote Sensing.

[8] Sahai, Baldev, Kalubarme, M.H. and Jadav, K.L., (1983). Ecological Studies in Ukai Command Area, International Journal of Remote Sensing, 6(3), p.p. 401-409.

[9] Srivastava, P. K. and Bhattcharya, A. K. (2000). Delineation of Groundwater potential zones in a hard rock terrain of Bargarh district, Orissa using IRS Data. Photonirvachak, Journal of the Indian Society of Remote Sensing, Vol. 17, pp. 35-42.

[10] Subba Rao, N. (2000). Important considerations for the success of rainwater harvesting. Current Science, Vol. 79, pp. 7.

[11] Waters, P., D., Greenbaum, P. Smart and H. Osmaston (1990). Applications of Remote Sensing to Groundwater Hydrology, Remote Sensing Reviews, Vol. 4, no. 2, pp. 223-264. 